\title{
Mitigation of peat fires utilizing groundwater supply
}

\author{
Ari Sandhyavitri ${ }^{1 *}$, Bambang Sujatmoko ${ }^{1}$, Muhammad Yusa $^{1}$, and Vito Charly ${ }^{1}$ \\ ${ }^{1}$ Department of Civil Engineering, Universitas Riau, Pekanbaru, Indonesia
}

\begin{abstract}
Mitigating the peat fire disasters in Indonesia during the dry season for more than 20 years (1997-2017) have obstructed by the limited accessibility of surface water resources (including water canals and rivers). Hence, there was a need to seek another opportunity to have access for the water for mitigating the peat fires from local shallow aquifer water resources. Various pumping tests have been conducted to explore the potential and characteristics of the shallow aquifer water for mitigating the peat fires in Riau, Indonesia. The groundwater transmission and storage (storativity) were tested using pump tests. The Cooper Jacob (a straight line) method had been applied to analyze the field data. This study has yielded the following results; the water transmissivity (T) was 1145.98 $\mathrm{m}^{2}$ /day, water storage (S) coefficient was $1.09 \times 10^{-3}$, and the deep depth of the shallow aquifer water (from the ground surface) was approximately 10 meter. Hence, this research identified that the potential shallow aquifer water produced from every single well in the surveyed area in Riau may reach $433.4 \mathrm{~m}^{3} /$ day. The amount of this water was considered more than enough to extinguish 4 ha of peat fire occurrences.
\end{abstract}

\section{Introduction}

Accessibility of surface water for fire suppression measures in peatland areas in Sumatra and Kalimantan islands, Indonesia during the dry season has been relatively limited $[1,2]$. Commonly the surface water resource for extinguishing the peat fires in Indonesia has been fetched from the water canals, river water, and ponds were relatively inadequate (Figure 1a). Various efforts for extinguishing peat fires have been conducted by the Regional Disaster Management Agency (BPBD) a non-departmental government agency, fire brigades, community fire awareness (MPA), Maggala Agni, Armed Forces, Policies, and the local government departments have become less effective in the absence of water resources (Fig. 1b).

Thus there is a need to seek an opportunity to find water resource alternatives for conducting the peat fire-fighting. This paper explored an alternative water resource from the shallow aquifer groundwater resources to extinguish the peatland fires in Riau. This study also investigated the potential of groundwater availability in the study areas.

The research method used in this study through pumping tests. The pumping tests data was utilized to calculate the coefficient of aquifer parameters such as; transmissivity

* Corresponding author: ari.sandhyavitri@,lecturer.unri.ac.id 
coefficient (T) and groundwater storage coefficients (storativity, S). Then these two parameters can be used to estimate the potency of the groundwater availability.
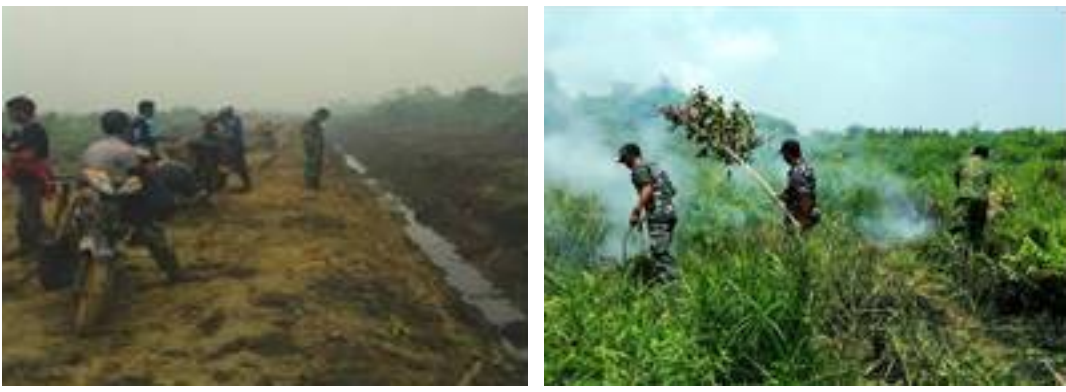

Fig. 1. (a) the water channels are dry during the dry season, (b) less effective peatland fire suppression measures in the absence of water.

The research study was located at Desa Rantau Baru, Pangkalan Kerinci District, Pelalawan regency, Riau province, Indonesia at the coordinate $0^{\circ} 20^{\prime} 26.9^{\prime \prime} \mathrm{N} 101^{\circ} 49^{\prime} 32.0^{\prime \prime} \mathrm{E}$ (Fig. 2).

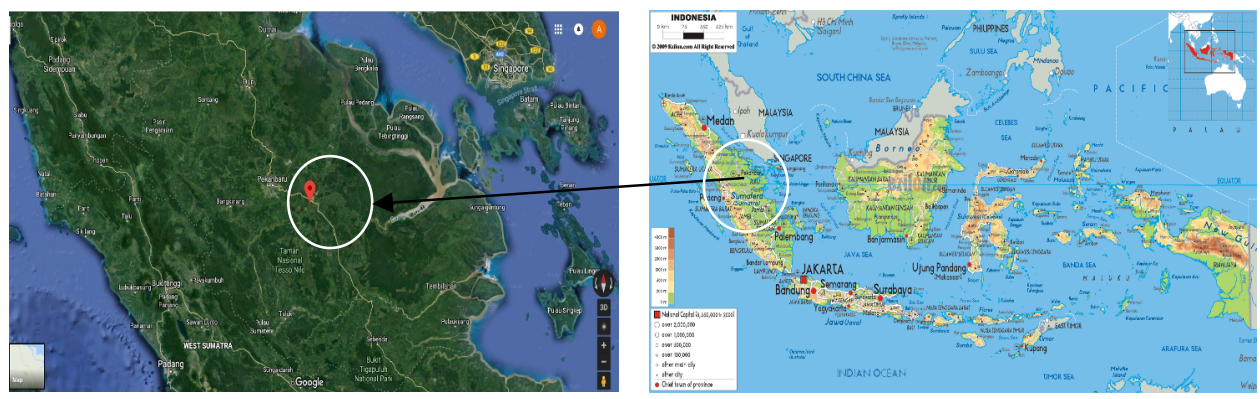

Fig. 2. Research location at desa Rantau Baru, Indonesia.

\subsection{Water potential}

The groundwater is an important component in the hydrological cycle within a watershed. Unlike surface water that does not have storage capacity (due to its free flow at a certain speed), the groundwater tends to flow more slowly and may have large storage capacity (GOI, 204). Thus, the groundwater balance has to be maintained so that its existence is guaranteed, especially during the dry season where there is a deficiency condition of the existing surface water [3].

Water hydrology in this study is concerned in managing the balance between water discharge and in charge, thus identify the potency of groundwater availability [4, 5]. Uncontrolled use of groundwater will indirectly affect to dry surface water [6] as well as land subsidence. There are various parameters used in calculating hydrology and water balance. According to Kodoatie [7] and Bower [8], the potential of groundwater flow depends on its flow, water discharge and in-charge.

In order to estimate the potency or quantity of groundwater (especially shallow aquifer water), it can be determined by an empirical calculation [9]. The estimation of the groundwater discharge can be obtained by calculating the amount of water release in the form of evapotranspiration (evaporation from the land and crops), and water intake (pumped from the well). The calculation of the discharge of the groundwater pumping at the pump well is the dynamic $[10,11]$. According to Luknanto [12], hydraulics of wells in 
groundwater flow is based on the type of aquifer. There are two types of aquifers; (a) unconfined aquifer (un-pressurized aquifer), and (b) confined aquifer (pressurized aquifer).

\subsection{Transmissivity dan storativity of the aquifer}

An aquifer groundwater availability can be tested by conducting continuous pumping tests at a constant discharge for 45 minutes. These pumping tests were performed to observe the decrease of groundwater level, and it affects to the other existing wells' water level locating within the surveyed area (Groundwater Management and Utilization Service, 2008 in Susiloputri \& Farida [13] The succeeding test are recovery tests. These tests were conducted after performing the continuous pumping tests. These recovery tests were done after the pumping machine is turned off. Then, it was observed the increase in the groundwater level (water recharge).

According to Todd \& Mays [10] and USBR [14], these constant pumping tests, and recovery tests can be conducted on the condition of an unconfined aquifer (un-pressurized aquifer) (Fig. 3). The final tests will yield two aquifer coefficients, such as; transmissivity coefficient (T) and storage coefficient (storativity, S).
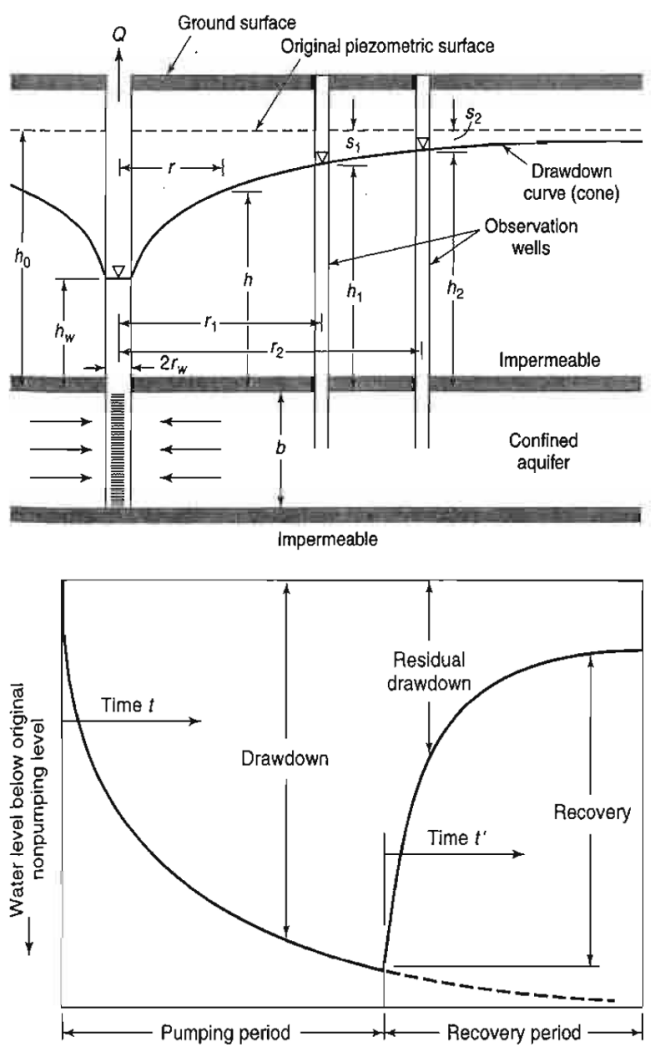

Fig. 3. Drawdown and recovery curves in the observation wells nearby a pumping well [10].

According to Cooper Jacob $[10,14,15]$, the relationship between the duration $(t)$ since pumping begins and the water level declines $(s)$ in the observation well tends to form a straight line (Eq. 1, 2): 


$$
\begin{gathered}
T=\frac{2.3 \times Q}{4 \times \pi \times \Delta s} \\
S=\frac{2.25 \times T \times t_{0}}{r^{2}}
\end{gathered}
$$

with $T$ is the transmissivity coefficient ( $\mathrm{m}^{2} /$ day), $S$ is the storage coefficient (storativity), $Q$ is the magnitude of the pumping discharge $\left(\mathrm{m}^{3} /\right.$ day), $\Delta s$ is the difference $\mathrm{s}$ in a logarithmic cycle in $\mathrm{t}$, to is the time for $\mathrm{s}=0$ (days), $r$ is the distance between the pumping well and the test/observation well (m).

As long as the calculation is based on a fixed $Q$ at a recovery test, $t$ is the time from start of pumping, $t^{\prime}$ is the time after pumping is stopped, $s$ is the difference between the initial level of the water surface and the final level of surface water recovery. The relationship between $s$ and $\log \left(t / t^{\prime}\right)$ is closer to yield a straight line. Thus the following formula can be defined $[10,11]$ :

$$
T=\frac{0.183 Q}{s} \log \frac{t}{t^{\prime}}
$$

In the logarithmic cycle, $\log \left(t / t^{\prime}\right)=1$ and delta between the initial level (original) of the water surface and the final level of surface water recovery is $\Delta s$, then:

$$
T=\frac{0.183 Q}{\Delta s}
$$

The water at the tested well is then pumped (Q1). The water level at the tested well is the function of the power of the pumps. The bigger the pump's power, the more water level declining. The decrease of the groundwater level in the tested well differs from the decrease of the water level in the other wells (Fig. 4), this depends on the distance between the wells.

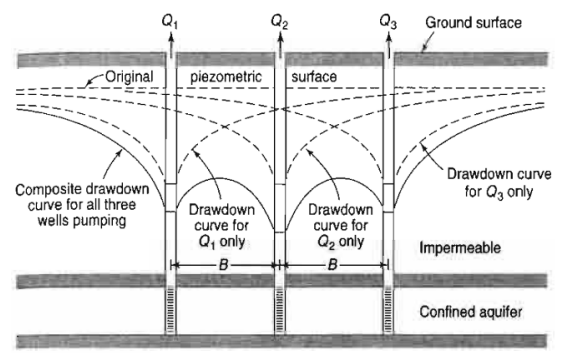

Fig. 4. Individual and composite drawdown curves for three wells in a line [10, 12].

\section{Methodology}

The electrical resistivity tomography (ERT) was applied in this study to mapping the subsoil layers at Desa Rantau Baru. The ERT is a geophysical technique for mapping subsurface structures of soil layers $[16,17]$. The electrical resistivity conducted some electrodes to investigate the soil layers. The arrangement of the electrodes in this research using the Wenner configuration utilizing a constant spacing of 32 electrodes with a common mid-point [18] (Fig. 5). 


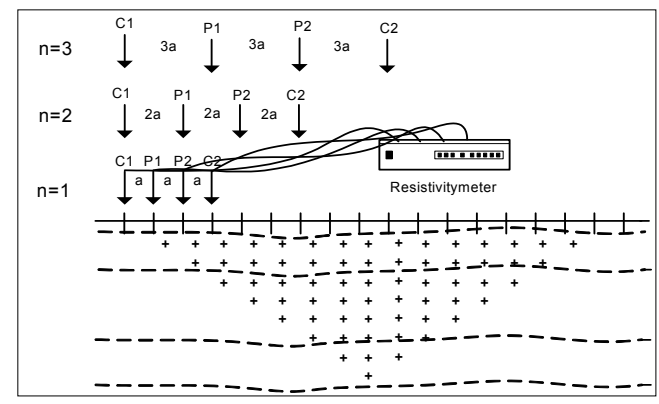

Fig. 5. Wenner electrodes configuration.

It is an assumption that the deep peat depth in the survey location is more than $8 \mathrm{~m}$, then in the field, it was used $32 \mathrm{~m}$ electrodes encompassing $1.5 \mathrm{~m}$ x 32 electrodes $=48 \mathrm{~m}$ of the cable length. The ERT results are also known as electrical resistivity imaging (ERI) (Fig. 6a).
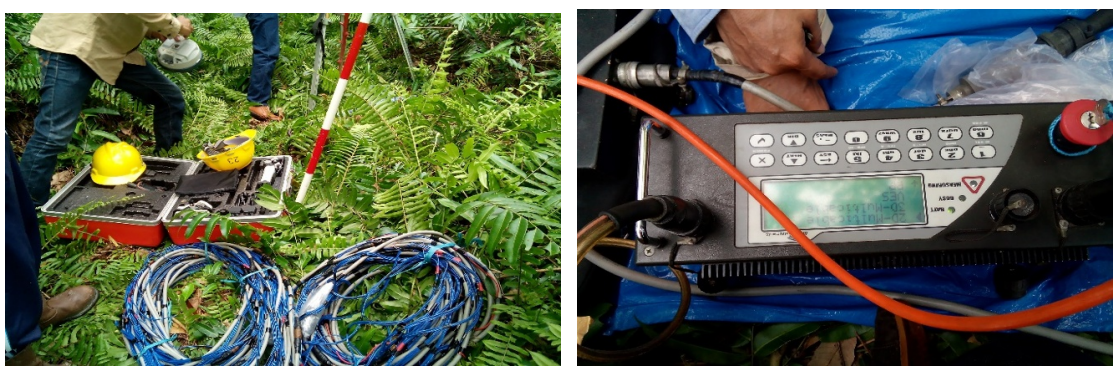

Fig. 6. (a) Electrode and wires of Electrical resistivity tomography (ERT), (b) Switcbox (Geoscanner).

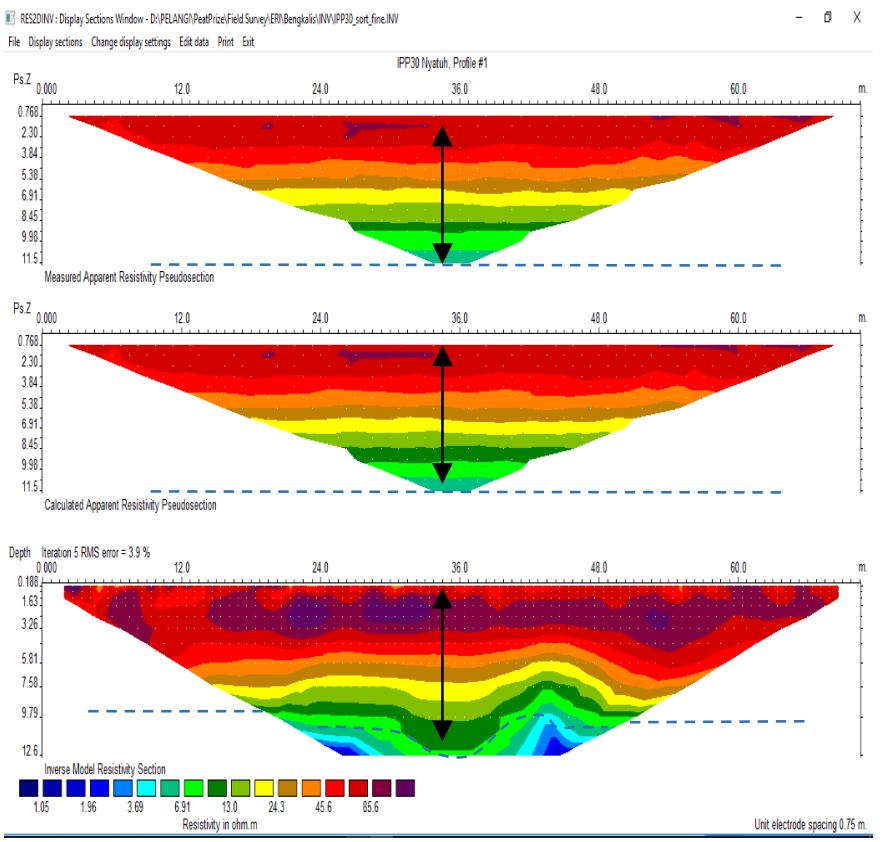

Fig. 7. Various peat soil layers resulted from ERI. 


\begin{tabular}{|c|c|c|c|c|}
\hline \multicolumn{5}{|c|}{ BORING LOG } \\
\hline $\begin{array}{l}\begin{array}{l}\text { Depth } \\
\text { (m) }\end{array} \\
\end{array}$ & $\begin{array}{l}\text { Soil } \\
\text { Type }\end{array}$ & Note & $\begin{array}{ll}\text { Von Post } \\
\text { Range }\end{array}$ & Picture \\
\hline $0.0-0.5$ & Peat & fibric & $\mathrm{H} 2$ & 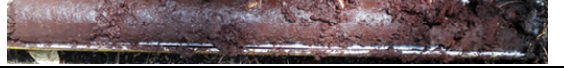 \\
\hline $0.5-1.0$ & Peat & fibric & $\mathrm{H} 2$ & 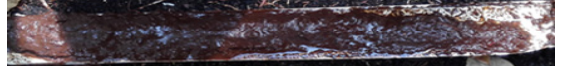 \\
\hline $1.0-1.5$ & Peat & fibric & $\mathrm{H} 2$ & 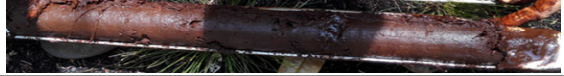 \\
\hline $1.5-2.0$ & Peat & fibric & $\mathrm{H} 2$ & \\
\hline $2.0-2.5$ & Peat & fibric & $\mathrm{H} 2$ & \\
\hline $2.5-3.0$ & Peat & fibric & $\mathrm{H} 2$ & 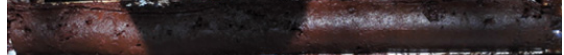 \\
\hline $3.0-3.5$ & Peat & fibric & $\mathrm{H} 2$ & arisinges \\
\hline $3.5-4.0$ & Peat & fibric & $\mathrm{H} 2$ & 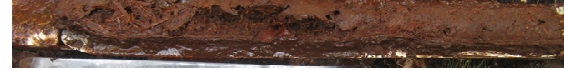 \\
\hline $4.0-4.5$ & Peat & fibric & $\mathrm{H} 2$ & \\
\hline $4.5-5.0$ & Peat & fibric & $\mathrm{H} 2$ & 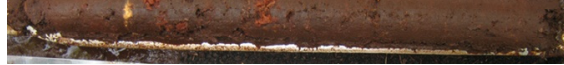 \\
\hline $5.0-5.5$ & Peat & fibric & $\mathrm{H} 2$ & $219+5$ \\
\hline $5.5-6.0$ & Peat & fibric & $\mathrm{H} 2$ & \\
\hline $6.0-6.5$ & Peat & fibric & $\mathrm{H} 2$ & 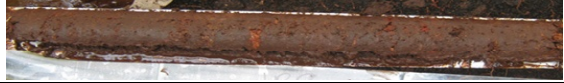 \\
\hline $6.5-7.0$ & Peat & fibric & $\mathrm{H} 2$ & \\
\hline $7.0-7.5$ & Peat & fibric & $\mathrm{H} 2$ & Sow \\
\hline $7.5-8.0$ & Peat & fibric & $\mathrm{H} 2$ & 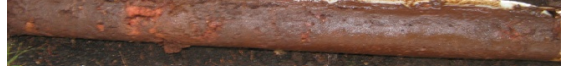 \\
\hline $8.0-8.5$ & Peat & fibric & $\mathrm{H} 2$ & 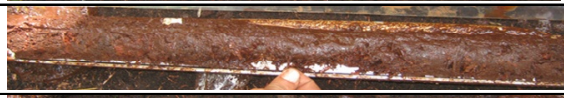 \\
\hline $8.5-9.0$ & Peat & fibric & $\mathrm{H} 2$ & 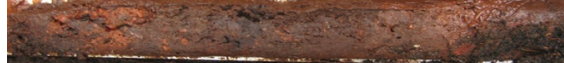 \\
\hline $9.0-9.5$ & $\begin{array}{l}\text { clayey } \\
\text { Peat }\end{array}$ & & & 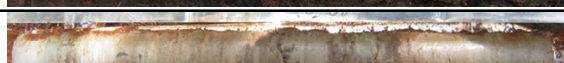 \\
\hline $9.5-10.0$ & Clay & & & 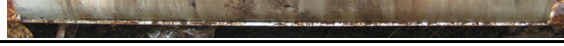 \\
\hline
\end{tabular}

Fig. 8. Soil layer resulted from the hand auger tests.

\section{Results and discussion}

The deep depth of the existing groundwater table and the soil layers in Bengkalis was presented in Fig. 7. Based on the peat resistivity imaging above, the average peat thickness at the research location and the layer of aquifer water can be estimated by averaging three areas of the peat thickness at left, middle and right-hand sides of the ERI images. It is 
measured that the peat thicknesses as follow; $9.2 \mathrm{~m}, 9.7 \mathrm{~m}$, and $9.1 \mathrm{~m}$ respectively. Thus the average thickness of the peat soil layers is $9.3 \mathrm{~m}$ and the water depth $>9.5 \mathrm{~m}$ (Fig. 7). This result confirms the hand auger test result. The test stated that there was peat soil layer up to $9.5 \mathrm{~m}$ soil depth, and after $9.5 \mathrm{~m}$ there was a clay soil layer, and after $10 \mathrm{~m}$ depth, there was shallow aquifer water (Fig. 8).

\subsection{Pumping tests}

The pumping tests in this study consisted of 3 monitoring wells and one testing (production) well. The monitoring wells were used to measure the fluctuation of the shallow groundwater aquifer levels while the production well is pumped. The distance between these four wellswas set up @10 m (Fig. 9).

The pumping tests consist of two stages such as continuous pumping tests and recovery tests (Fig. 9). The pumping tests were conducted two times at the minimum repetitions to control its consistency results. It was calculated that the water discharge 1.83 liters/second $\left(158.04 \mathrm{~m}^{3} /\right.$ day $)$ to 2.76 liters/ second $\left(238.83 \mathrm{~m}^{3} /\right.$ day $)$. After conducting these pumping tests, the drawdown has reached its steady state.

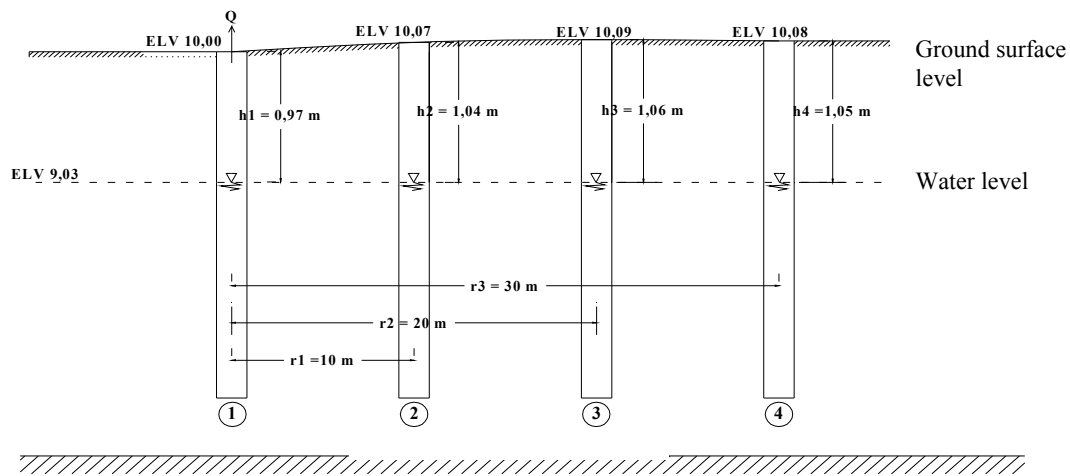

Fig. 9. Pumping tests for 3 monitoring wells and 1 testing (production) well.

Table 1. Pumping tests recapitulation.

\begin{tabular}{|c|c|c|c|c|c|c|}
\hline & \multirow{2}{*}{$\begin{array}{l}\text { Monitor } \\
\text { Wells }\end{array}$} & \multirow{2}{*}{$\mathbf{r}(\mathbf{m})$} & \multicolumn{2}{|c|}{$\begin{array}{c}\text { Transmisivity }(T) \\
\left(\mathrm{m}^{2} / \text { day }\right)\end{array}$} & \multicolumn{2}{|c|}{ Storativity (S) } \\
\hline & & & Continuous & Recovery & Continuous & Recovery \\
\hline \multirow{3}{*}{$\overrightarrow{\vec{D}}$} & 2 & 10 & 1145.98 & 930.51 & $1.09 \mathrm{E}-03$ & - \\
\hline & 3 & 20 & 2442.36 & 1864.37 & $2.73 \mathrm{E}-03$ & \\
\hline & 4 & 30 & 3151.26 & 3555.62 & $1.59 \mathrm{E}-03$ & - \\
\hline \multirow{3}{*}{ 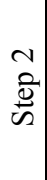 } & 3 & 10 & 1165.03 & 249.63 & $1.35 \mathrm{E}-03$ & - \\
\hline & 2 & 20 & 1311.45 & 1055.70 & $1.10 \mathrm{E}-03$ & \\
\hline & 1 & 30 & 5987.41 & 1060.07 & $3.46 \mathrm{E}-02$ & - \\
\hline
\end{tabular}

Table 1 shows that the pumping test yield a transmissivity coefficient was 1145.98 $\mathrm{m}^{2} /$ day, and storativity coefficient (S) was $1.09 \times 10^{-3}$. Based on the recovery test it was 
identified that the transmissivity $(T)$ coefficient was $930.51 \mathrm{~m}^{2} /$ day. The transmissivity coefficient of this pumping test as well as the recovery tests will be used to determine the potential of the shallow aquifer water (groundwater) availability $(Q)$. The potential of the shallow water availability at the study area can be determined by the trial and error of various $\mathrm{Q}$ coefficients. The coefficient of transmissivity $(T)$ at the period of the pumping tests will be equal to the transmissivity $(T)$ coefficient at the period of recovery tests (Fig. $10)$.

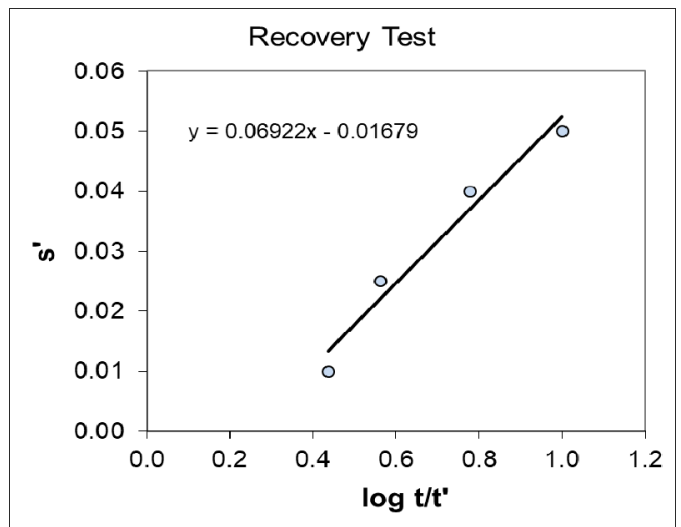

Fig. 10. Correlation between $t / t$ ' and $s^{\prime}$ at recovery tests.

The recovery graph (Fig. 8) has yielded the following equations:

$$
s=0.06922 \log \frac{t}{t^{\prime}}-0.01679
$$

At the period of $s=0, t=\mathrm{t}_{0}$, will be:

$$
0=0.06922 \log \frac{t}{t^{\prime}}-0.01679
$$

Then,

$$
\log \left(\frac{t}{t^{\prime}}\right)_{0}=\frac{0.01679}{0.06922}=0.24256
$$

Then,

$$
\begin{aligned}
& \left(\frac{t}{t^{\prime}}\right)_{0}=10^{0.24256} \\
& \left(\frac{t}{t^{\prime}}\right)_{0}=1.74807 \text { minutes }=0.00121 \text { day } \\
& \Delta \mathrm{S}=0.06922 \mathrm{~m} \\
& \mathrm{Q}=433.40 \mathrm{~m}^{3} / \text { day (trial and error tests) } \\
& T=\frac{2.3 \times Q}{4 \times \pi \times \Delta s}=\frac{2.3 \times 433.4}{4 \times 3.14 \times 0.06922}=1145.98 \mathrm{~m}^{2}
\end{aligned}
$$


The $\mathrm{T}$ coefficient during recovery test equal to $\mathrm{P}$ coefficient at the pumping tests of $1145.98 \mathrm{~m}^{2}$ /day. Hence, using trial and error to obtain the potential shallow aquifer water (Q) at the field was $433.4 \mathrm{~m}^{3} /$ day.

According to a previous study conducted at the University of Indonesia's Thermodynamic laboratory, it was found that there was required approximately 6-10 liters of water for extinguishing $10 \times 10 \times 10 \mathrm{~cm}$ of peat [19]. Thus, for a $433.4 \mathrm{~m}^{3}$ of water, theoretically may be able to extinguish about 3-4 hectares of peat fires (with the average 1 $\mathrm{cm}$ depth of water).
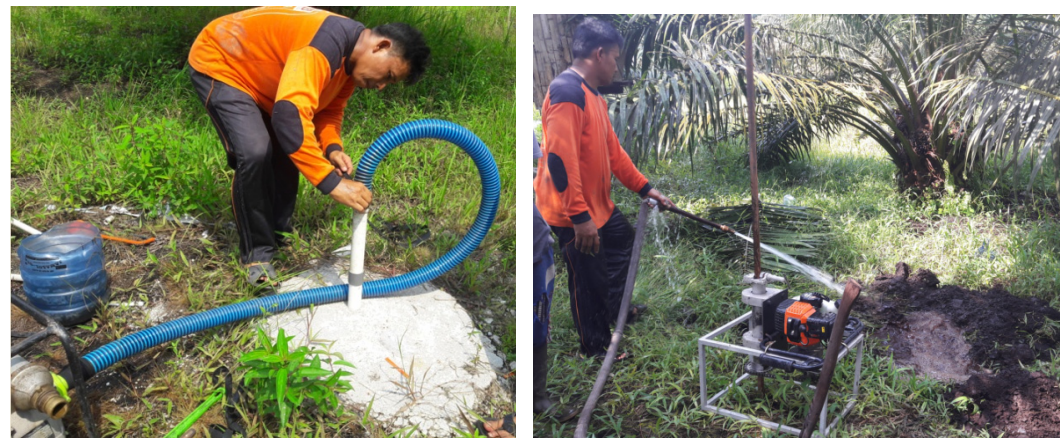

Fig. 11. Utilizing shallow aquifer water for extinguishing peat fires in Kampar, September 2016.

The distribution of water for extinguishing peat fires was used pumps and 100-200 m fire brigade pipes. This method was applied in the case of peat fires at Kampar, Riau Province September 2016 (Fig. 11).

\section{Conclusions}

The transmissivity $(T)$ at the period of pumping tests were calculated at $1145.98 \mathrm{~m}^{2} /$ day and the period of the recovery tests was $930.51 \mathrm{~m}^{2} /$ day. The storativity coefficient $(S)$ was calculated as $1.09 \times 10^{-3}$. Hence, the potential availability of groundwater at the research location was estimated at $433.4 \mathrm{~m}^{3} /$ day. This amount of potential shallow aquifer water can be used for extinguishing the peat fires approximately 3-4 ha/well.

\section{References}

1. A. Sandhyavitri, M.A. Perdana, S. Sutikno, F. H. Widodo, IOP Conf. Series: Materials Science and Engineering 309, 1 (2018)

2. M.E. Harrison, S.E. Page, S. H. Limin, J. of Biological Education 56, 3 (2009)

3. R. Bonita, M.A. Mardyanto, J. Teknik Inst. Teknologi Sepuluh Nopember 4, 1 (2015)

4. S.H. Brotowiryatmo, Hidrologi: teori, masalah dan penyelesaian (Nafiri, Yogyakarta, 2000)

5. Suyono, Hidrologi dasar (Universitas Gajah Mada, Yogyakarta, 2008)

6. Harjito, Jurnal Sains dan Teknologi Lingkungan 6, 2 (2014)

7. R.J. Kodoatie, Pengantar hidrogeologi (Penerbit Andi, Yogyakarta, 1996)

8. H. Bouwer, Groundwater hydrology (McGraw-Hill, New York, 1978)

9. K.N. Brooks, P. Ffolliott, H. Gregersen, T. John, Hydrology and the management of watersheds (Iowa State University Press, Iowa, 1991) 
10. D.K. Todd, L.W. Mays, Groundwater hydrology (John Wiley \& Son, New York, 2005)

11. R.K. Linsley, M.A. Kohler, J.L.H. Paulhus, Hydrology for engineers (McGraw-Hill, New York, 1982)

12. D. Luknanto, Aliran air tanah (Universitas Gajah Mada, Yogyakarta, 2000)

13. S. Susiloputri, N.S. Farida, Pemanfaatan air tanah untuk memenuhi air irigasi di Kabupaten Kudus Jawa Tengah (Universitas Diponegoro, Semarang, 2011)

14. U.S. Bureau of Reclamation, Groundwater manual (U.S Department of the Interior, Washington D.C., 1995)

15. L. Syarif, Penentuan nilai karakteristik akuifer sumur air tanah melalui uji pemompaan (pumping test) dengan metode Cooper-Jacob di Leuwikopo, Darmaga (Institut Pertanian Bogor, Bogor, 2003)

16. T. Gunther, C. Rucker, Proceeding of Schlumberger Symposium - 100 years of Electrical Imaging Conference (2012)

17. W. Daily, W. Mondt, Electrical Resistance Tomography for Subsurface Imaging (Lawrence Livermore National Laboratory, United States, 2000)

18. D.M. Nurjaman, Aplikasi electrical resistivity tomography (Ert) untuk pemetaan gambut (Pusat Teknologi Pengembangan Sumberdaya Mineral Kedeputian Bidang Teknologi Pengembangan Sumberdaya Alam Badan Pengkajian dan Penerapan Teknologi, 2017).

19. Y. S. Nugroho, Fire safety engineering lecture module (Universitas Indonesia, Depok, 2018) 